\title{
Metal Concentration in Sediments from the Santos Estuarine System: a Recent Assessment
}

\author{
Isabella C. A. C. Bordon, ${ }^{*, a}$ Jorge E. S. Sarkis, ${ }^{a}$ Gustavo M. Gobbato, ${ }^{a}$ \\ Marcos A. Hortellani ${ }^{a}$ and Claudia M. Peixoto ${ }^{b}$
}

${ }^{a}$ Centro de Química e Meio Ambiente, Instituto de Pesquisas Energéticas e Nucleares (IPEN), Av. Prof. Lineu Prestes no. 2242, Cidade Universitária, 05508-000 São Paulo-SP, Brazil

${ }^{b}$ Centro de Desenvolvimento da Tecnologia Nuclear (CDTN, Campus da UFMG), Av. Pres. Antônio Carlos, 6.627, 31270-901 Belo Horizonte-MG, Brazil

\begin{abstract}
O presente estudo avaliou a concentração de metais em sedimentos provenientes do Sistema Estuarino de Santos (Estado de São Paulo, Brasil) no inverno de 2010. Amostras de sedimento superficial foram coletadas em 16 pontos distribuídos ao redor do referido estuário. Cada amostra foi homogeneizada e sub-amostrada para as análises químicas e granulométricas. Os resultados foram comparados aos valores de referência presentes nas Normas Canadenses de Qualidade do Sedimento. As análises de componentes principais (ACP) e de clusters foram utilizadas para identificar e esclarecer correlações existentes entre os pontos de coleta e os parâmetros químicos. ACP agrupou locais próximos à área industrial, onde a contaminação do sedimento parece ser mais crítica, o que foi confirmado pela análise de clusters. Os resultados confirmaram que a contaminação por metais ainda é um problema para o ecossistema bentônico do Estuário de Santos. Esforços devem ser feitos para continuar permitindo a recreação, a pesca e demais atividades diretamente relacionadas com as zonas costeiras e ajudar a proteger o ecossistema estuarino.
\end{abstract}

This study aimed to evaluate the metal concentration of sediments from the Santos Estuarine System (Sao Paulo State, Brazil). during the winter of 2010. Surface sediment samples were collected from 16 sites distributed along with the estuarine system. Aliquots from homogenized samples were sub-sampled for chemical and granulometric analyses. The results were compared with reference values from Canadian Sediment Quality Guidelines. Principal components analysis (PCA) and cluster analysis were used to identify and clarify relationships among sites and chemical parameters. PCA grouped sites close to the industrial area, where sediment contamination seems to be more critical, which was confirmed by cluster analysis. The results confirmed that metal contamination is still a problem for the bent ecosystem of the Santos Estuarine System. Strong efforts must be done to keep allowing recreation, fishing and other activities direct related to coastal areas and to help protect the estuarine ecosystem.

Keywords: Santos Estuarine System, sediment, metals, contamination, Brazil

\section{Introduction}

Despite the implementation of contamination control policies, anomalously high levels of multiple contaminants have still been recorded in coastal sediment of the Santos Estuarine System in the São Paulo State (Southeastern Brazil). ${ }^{1}$ This setting is historically, economically and environmentally important at a regional scale. Human activities in the estuary started in the beginning of the $16^{\text {th }}$ century, right after the arrival of the first Portuguese explorers in Brazil. The most important petrochemical

*e-mail: isabella.bordon@gmail.com and metallurgical industrial areas of Brazil (the industrial complex of Cubatão City) and the largest commercial harbor of South America (the harbor of Santos City) are also located inside the estuarine system, in the metropolitan region of Baixada Santista, which is densely urbanized. Although this region is well-known because of its distinct economical significance, it also has noticeable environmental importance since the mangroves, which surround the whole area, correspond to $43 \%$ of total mangrove area of the São Paulo State. ${ }^{2}$

Especially from 1950s, when activities of the industrial complex of Cubatão City (São Paulo State) started, this estuarine system has been seriously contaminated. In the 
early 1980s, emissions of gases, liquids and solids from chemical, petrochemical, steel and fertilizer industries transformed the Cubatão City into one of the most contaminated scenarios. Furthermore, the sewage due to the urbanization process has likewise affected the environmental quality. Government programs, which are led by Companhia de Tecnologia de Saneamento Ambiental (CETESB), associated with the Environmental Department of São Paulo State (SEMA-SP), have initiated the control of industrial emissions in the impact area of this industrial complex since $1984 .^{3}$

Sediments are an important environmental compartment for aquatic evaluation, since they may accumulate contaminants in higher concentration than those observed in the water column. The effects are negative to the benthic biota and to the organisms that feed on the benthos or on the sediment. ${ }^{4}$ The absorption of organic and inorganic particles by sediment grains within chemical and physical factors, that make these particles available to the biota, favors the persistence of the contamination, showing the importance of monitoring sediment to protect aquatic ecosystems.

The quality of the sediments from the Santos Estuarine System has already been studied with the purpose of environmental diagnosis and monitoring, mainly for metal concentration. ${ }^{1,2,4-8}$ Metals occur naturally in varying concentration according to the geological matrix. However, high levels of metals in sediments are mostly associated with human activity and may be available to organisms. Thus, this study aimed to evaluate metal concentration of sediments from the Santos Estuarine System during the winter of 2010, providing recent information about the theme.

\section{Experimental}

\section{Sediment samples}

During the winter of 2010, surface estuarine sediment samples were collected from 16 sites (Figure S1 in the Supplementary Information) distributed along the estuarine system with an Ekman grab sampler. Water temperature and salinity were measured immediately after sediment collection. From the retained material, only the $2 \mathrm{~cm}$ superficial layer from the sediment not in contact with the grab sampler walls was composited. Aliquots of the homogenized samples were then sub-sampled for chemical and granulometric analyses. Some sites were chosen close to important industrial activities, such as the main oil company in Brazil ( sites 10, 11 and 12), the local steel industry (sites 13, 14 and 15), the harbor of Santos City (sites 8 and 9) and waste deposit areas (site 4). These activities release emission of metals from their current processes, according to many studies. Immediately after collection, samples were carried to the laboratory and stored at $-20^{\circ} \mathrm{C}$.

\section{Granulometric analyses}

Grain-size distribution was analyzed by the dry sieving method according to Abessa et al. ${ }^{5}$ Sediment aliquots ( $30 \mathrm{~g}$ ) were dried at ambient temperature for $72 \mathrm{~h}$. Then, they were sieved for 15 min using a set of sieves in the Went-Worth scale. In this research, only mud $(<63 \mu \mathrm{m})$ was considered for the discussion since this category is responsible for the most part of metal absorption in sediment.

\section{Metal analyses}

The concentrations of the following metals were analyzed: $\mathrm{Al}, \mathrm{Cd}, \mathrm{Cr}, \mathrm{Co}, \mathrm{Cu}, \mathrm{Fe}, \mathrm{Hg}, \mathrm{Mn}, \mathrm{Ni}, \mathrm{Pb}$ and $\mathrm{Zn}$. Before the extraction, the sediment samples were dried at ambient temperature and sieved in a $2 \mathrm{~mm}$ net. Digestion in high pressure microwaves system was used (CEM Corporation, model MDS-2000). The acid extraction solution consisted of a mixture containing $9 \mathrm{~mL}$ of $\mathrm{HNO}_{3}$ sub-boiling and $3 \mathrm{~mL}$ of $\mathrm{HCl}$ sub-boiling, according to USEPA method 3051A recommendations. ${ }^{9}$ This mixture was added to $0.5-1.0 \mathrm{~g}$ of sediment samples and/or certified material reference in microwave HP-500 vessels (PFA Teflon, fluorocarbon polymer), which were appropriately sealed and heated in the microwave unit. The digestion was made according the following parameters: power of $600 \mathrm{~W}$, temperature ramp time of $9 \mathrm{~min}$, temperature of $175^{\circ} \mathrm{C}$ and hold time of $4.5 \mathrm{~min}$. After cooling, the vessel content was transferred to $50 \mathrm{ml}$ centrifuge vial and the volume was made up to $40 \mathrm{~g}$ with water (Milli-Q) with a resistivity $18 \mathrm{M} \Omega \mathrm{cm}$ at $25{ }^{\circ} \mathrm{C}$. The metal analysis was performed after the decanting or centrifugation of residues of the vial content.

In accordance with the Method 3051A, this method is not intended to accomplish total decomposition of the sample and the extracted analyte concentrations may not reflect the total content in the sample. According to Abessa, ${ }^{10}$ in ecosystems such as an estuary there are many species, each one subjected to a level of metal exposition. Thus, it is not possible to access all the potential available contaminants by any acid extraction. Therefore, methods such as $3051 \mathrm{~A}$, which uses acids like $\mathrm{HNO}_{3}$ and $\mathrm{HCl}$ (for extracting metals strongly absorbed by organic matter and fines), are very useful to estimate the sediment capability to transfer metals to biota. This type of extraction methodology also enables the comparison between the obtained values 
and guideline levels, such as TEL (Threshold Effect Level) and PEL (Probable Effect Level) from Canadian Sediment Quality Guidelines.

For $\mathrm{Al}$ and $\mathrm{Fe}$, the original extract was diluted 100 times before the determination. Cd concentration was determined by a high-resolution ICP-mass spectrometer (HR-ICP-MS, Finnigan MAT Element). Al, Cr, $\mathrm{Co}, \mathrm{Cu}, \mathrm{Fe}, \mathrm{Mn}, \mathrm{Ni}, \mathrm{Pb}$ and $\mathrm{Zn}$ concentrations were measured using fast sequential flame atomic absorption spectrometer (FS-FAAS, Varian model Spectr-AAS-220-FS). Particularly, Hg concentration was measured by cold vapor generation. The spectrophotometer was coupled to a typical FIA (flow analysis injection) manifold, with a manual injection valve that injects $500 \mu \mathrm{L}$ of digested sample at a flow of Milli-Q water $\left(10 \mathrm{~mL} \mathrm{~min}^{-1}\right)$. The $\mathrm{Hg}^{2+}$ is reduced on line by $\mathrm{SnCl}_{2}$ $25 \%(\mathrm{~m} / \mathrm{v})$ in $\mathrm{HCl} 25 \%(\mathrm{v} / \mathrm{v})$ at a flow of $1 \mathrm{~mL} \mathrm{~min}^{-1}$. Argon was used as a carrier gas at a constant flow of $200 \mathrm{~mL} \mathrm{~min}^{-1}$.

The validation of this method was performed by analyzing certificate reference sediments (SRM 2704 Buffalo River Sediment).

Total organic carbon (TOC) was also measured by the infrared technique using the equipment LECO CS-400. The sample is subjected to total combustion and an infrared sensor detects the carbon dioxide $\left(\mathrm{CO}_{2}\right)$ generated by combustion, immediately linking to the amount of elemental carbon in the sample.

\section{Descriptive and statistical treatment}

The results obtained by the chemical analysis of metals were compared with reference values of the Canadian Sediment Quality Guidelines, ${ }^{11}$ which were also adopted by Lamparelli et al. ${ }^{2}$ TEL is the limit below which no adverse effects on the biological community are observed, and PEL is the probable level where an occurrence of adverse effects in the biological community happens. Mud content and TOC were used for comparison.

A correlation matrix with chemical parameters, mud content and TOC was carried out to recognize previous relationships in order to identify possible processes related to metal deposition in sediments. Correlation analysis was performed on the data matrix using the Pearson coefficient, according to Zar ${ }^{12}$ at $\alpha=0.05$ significance level. Principal components analysis was used to detect interrelationships among sites, chemical parameters, mud content and TOC. Cluster analysis, frequently applied to environmental evaluation, was used to group samples according to their similarities.

\section{Results and Discussion}

\section{Validation of the method}

Method validation was accomplished analyzing the reference material (Buffalo River Sediment) in three replicates. The recovery of Buffalo River Sediment samples for most metals during the validation process was $>80 \%$. The Buffalo River Sediment is certificated for total extraction of metals, which explains the low recovery for $\mathrm{Cr}(52.19 \%)$ and $\mathrm{Al}(27.33 \%)$ (Table 1).

$\mathrm{Al}$ and $\mathrm{Cr}$ are known as refractory elements, strongly connected to silicates that are difficult to digest and also explaining the low recovery of these metals. According to Method 3051A, silicates may not be dissolved and in some cases may isolate target analyzed elements. These results are in agreement with other studies in this perspective. ${ }^{8,13,14}$ However, according to validation data presented by the Method 3051A for Buffalo River Sediment samples

Table 1. Measured values, certified values and recovery of Buffalo River Sediment samples

\begin{tabular}{|c|c|c|c|c|c|}
\hline Elements & $\begin{array}{l}\text { Measured value } / \\
\qquad\left(\mu \mathrm{gg}^{-1}\right)\end{array}$ & $\begin{array}{l}\text { Certified value } / \\
\qquad\left(\mu g^{-1}\right)\end{array}$ & $\begin{array}{c}\text { Recovery / } \\
\%\end{array}$ & $\begin{array}{l}\text { Certified value (USEPA 3051A) } / \\
\qquad\left(\mu \mathrm{g} \mathrm{g}^{-1}\right)\end{array}$ & $\begin{array}{c}\text { Recovery / } \\
\%\end{array}$ \\
\hline $\mathrm{Al}$ & $1.67 \pm 0.45 *$ & $6.11 \pm 0.16^{*}$ & 27.33 & - & - \\
\hline $\mathrm{Cd}$ & $3.00 \pm 0.04$ & $3.45 \pm 0.22$ & 85.02 & $3.62 \pm 0.17$ & 82.87 \\
\hline Co & $15.70 \pm 2.11$ & $14.0 \pm 0.6$ & 112.14 & - & - \\
\hline $\mathrm{Cr}$ & $70.46 \pm 6.46$ & $135 \pm 5$ & 52.19 & $77.1 \pm 12.6$ & 91.39 \\
\hline $\mathrm{Cu}$ & $90.63 \pm 3.76$ & $98.6 \pm 5.0$ & 91.91 & - & - \\
\hline $\mathrm{Fe}$ & $3.43 \pm 0.03 *$ & $4.11 \pm 0.10^{*}$ & 83.53 & - & - \\
\hline $\mathrm{Hg}$ & $1.65 \pm 0.04$ & $1.47 \pm 0.07$ & 112.00 & - & - \\
\hline $\mathrm{Mn}$ & $516.35 \pm 11.11$ & $555 \pm 19$ & 93.04 & - & - \\
\hline $\mathrm{Ni}$ & $36.00 \pm 1.87$ & $44.1 \pm 3.0$ & 80.79 & $42.2 \pm 3.2$ & 85.31 \\
\hline $\mathrm{Pb}$ & $149.81 \pm 11.68$ & $161 \pm 17$ & 93.05 & $161 \pm 17$ & 93.05 \\
\hline $\mathrm{Zn}$ & $431.39 \pm 34.43$ & $438 \pm 12$ & 98.49 & - & - \\
\hline
\end{tabular}

${ }^{\mathrm{a}}$ Mean $\pm \mathrm{SD}$; ${ }^{\mathrm{b}}$ Mean $\pm 95 \%$ confidence limit; *Values of $\mathrm{Al}$ and $\mathrm{Fe}$ are presented in percentage. 
digested using $9 \mathrm{~mL}$ of $\mathrm{HNO}_{3}$ and $3 \mathrm{~mL}$ of $\mathrm{HCl}, \mathrm{Cr}$ recovery ranged $91.39 \%$. It was considered an appropriated result, as well as $\mathrm{Cd}, \mathrm{Ni}$ and $\mathrm{Pb}$ recoveries.

\section{Metal concentration and mud content}

During the sampling period, water temperature ranged from 19.9 (sites 11 e 12 ) to $26^{\circ} \mathrm{C}$ (site 2) with a mean value of $22.4 \pm 2.1^{\circ} \mathrm{C}$ and salinity varied from 0 (sites 10,11 and 12) to $35 \mathrm{~g} \mathrm{~L}^{-1}$ (site 9) with an average of $21.6 \pm 14.4 \mathrm{~g} \mathrm{~L}^{-1}$. In this study, sites inside the Santos Estuarine System presented lower salinities than those nearby Santos Bay, mainly because of the influence of rivers that discharge low-salinity (and low-temperature) waters in the system. Thus, this fact may interfere in the availability of metals in some sites due to variation of both parameters, as previously recorded. ${ }^{10}$

Metal concentrations $\left(\mu \mathrm{g} \mathrm{g}^{-1}\right)$, mud content, TOC percentage, TEL and PEL values are resumed in Table 2.

The presented results show that $\mathrm{Hg}$ concentration was above TEL in most of the sites (except for sites 10, 14 and 16 ), varying between 0.03 (site 14) and $0.55 \mu \mathrm{g} \mathrm{g}^{-1}$ (site 12). Site 5 presented the only value above PEL in this study. These results are in the same order of magnitude of those found by other studies in the same estuary. ${ }^{2,48}$
$\mathrm{Cu}$ and $\mathrm{Ni}$ concentrations in sites 11, 12, 13 and 15 were above TEL. Zn concentration was above TEL in sites 12,13 and 15 and $\mathrm{Pb}$ value was above TEL only in site 13. These results were obtained probably due to influence of industrial effluents since these sites are close to several industrial activities located in Cubatão River and Piaçaguera Channel, among them, the main oil company of Brazil and the local steel industry.

Lamparelli et al. ${ }^{2}$ also recorded the presence of these metals in sediment as being related to industrial processes. It seems that site 5 is also influenced by these industrial effluents, since it is located in the end of Cubatão River and showed concentrations above TEL for the cited metals $(\mathrm{Cu}, \mathrm{Hg}$ and $\mathrm{Ni})$. Mud content in sites 5, 6, 12, 13 and 15 was higher compared to other sites. Since concentrations of metals increase with the decrease of the grain size due to the increase of available superficial area of the grain, ${ }^{15}$ the results confirmed the favorable characteristics that promoted high metal concentration in these sites, especially of $\mathrm{Hg}$ concentration in site 5 .

Although it is not common to find low concentration of mud in an estuarine system, Cesar et al. ${ }^{4}$ recorded low content of mud in the same area using a similar granulometric method. Due to the dynamic of the estuarine system, the content of superficial sediment varies even in

Table 2. Metal concentrations and mud content of sediment samples from the Santos Estuarine System. Values above TEL are in bold and values above PEL are in bold and underlined

\begin{tabular}{|c|c|c|c|c|c|c|c|c|c|c|c|c|c|}
\hline Sites & $\begin{array}{c}\mathrm{Al} / \\
\%\end{array}$ & $\begin{array}{c}\mathrm{Cd} / \\
\left(\mu \mathrm{g} \mathrm{g}^{-1}\right)\end{array}$ & $\begin{array}{c}\mathrm{Cr} / \\
\left(\mu \mathrm{g} \mathrm{g}^{-1}\right)\end{array}$ & $\begin{array}{c}\mathrm{Cu} / \\
\left(\mu \mathrm{g} \mathrm{g}^{-1}\right)\end{array}$ & $\begin{array}{c}\mathrm{Co} / \\
\left(\mu \mathrm{g} \mathrm{g}^{-1}\right)\end{array}$ & $\begin{array}{c}\mathrm{Fe} / \\
\%\end{array}$ & $\begin{array}{c}\mathrm{Hg} / \\
\left(\mu \mathrm{g} \mathrm{g}^{-1}\right)\end{array}$ & $\begin{array}{c}\mathrm{Mn} / \\
\left(\mu \mathrm{g} \mathrm{g}^{-1}\right)\end{array}$ & $\begin{array}{c}\mathrm{Ni} / \\
\left(\mu \mathrm{g} \mathrm{g}^{-1}\right)\end{array}$ & $\begin{array}{c}\mathrm{Pb} / \\
\left(\mu \mathrm{g} \mathrm{g}^{-1}\right)\end{array}$ & $\begin{array}{c}\mathrm{Zn} \mathrm{/} \\
\left(\mu \mathrm{g} \mathrm{g}^{-1}\right)\end{array}$ & $\begin{array}{c}\text { Mud / } \\
\%\end{array}$ & $\begin{array}{c}\mathrm{TOC} / \\
\%\end{array}$ \\
\hline 1 & 1.06 & 0.08 & 13.17 & 15.84 & 14.03 & 1.20 & 0.20 & 212.60 & 5.26 & 13.44 & 54.04 & 4.51 & 1.90 \\
\hline 2 & 0.56 & 0.05 & 6.48 & 2.88 & 1.07 & 0.58 & 0.14 & 78.17 & $<2.00$ & 1.37 & 20.36 & 1.46 & 2.20 \\
\hline 3 & 1.22 & 0.10 & 10.72 & 7.29 & 5.48 & 1.12 & 0.20 & 91.48 & 5.88 & 6.59 & 39.17 & 3.23 & 5.43 \\
\hline 4 & 1.15 & 0.11 & 14.54 & 9.24 & 7.43 & 1.59 & 0.34 & 168.77 & 5.59 & 7.04 & 59.91 & 3.68 & 2.40 \\
\hline 5 & 4.59 & 0.27 & 33.02 & 29.53 & 27.72 & 3.87 & $\underline{1.33}$ & 255.19 & 21.53 & 24.70 & 114.86 & 36.65 & 4.20 \\
\hline 6 & 0.95 & 0.10 & 11.46 & 5.95 & 4.14 & 1.64 & 0.19 & 136.76 & 6.44 & 3.10 & 42.30 & 10.67 & 7.79 \\
\hline 7 & 0.48 & 0.07 & 10.57 & 6.88 & 5.07 & 0.85 & 0.15 & 93.70 & 1.05 & 5.53 & 26.85 & 0.00 & 5.67 \\
\hline 8 & 0.77 & 0.05 & 8.10 & 3.88 & 2.07 & 0.81 & 0.19 & 104.33 & 2.76 & 3.72 & 32.56 & 0.71 & 1.19 \\
\hline 9 & 1.54 & 0.05 & 19.22 & 7.24 & 5.43 & 1.95 & 0.16 & 366.68 & 7.65 & 1.08 & 40.78 & 5.96 & 1.33 \\
\hline 10 & 1.22 & 0.04 & 15.88 & 15.07 & 12.05 & 1.58 & $<0.03$ & 160.70 & 9.65 & 4.44 & 51.14 & 0.78 & 0.43 \\
\hline 11 & 3.58 & 0.09 & 36.03 & 19.08 & 17.09 & 3.35 & 0.18 & 889.47 & 17.41 & 15.04 & 95.09 & 8.61 & 1.58 \\
\hline 12 & 3.63 & 0.23 & 30.83 & 35.43 & 20.14 & 3.45 & 0.55 & 316.33 & 23.53 & 18.37 & 180.27 & 16.53 & 5.00 \\
\hline 13 & 3.71 & 0.34 & 42.50 & 38.39 & 16.59 & 3.99 & 0.42 & 593.99 & 23.61 & 37.78 & 231.36 & 15.54 & 4.86 \\
\hline 14 & 1.36 & 0.06 & 12.54 & 6.44 & 9.57 & 1.45 & 0.03 & 165.66 & 5.50 & 3.71 & 46.25 & 1.17 & 2.65 \\
\hline 15 & 3.99 & 0.29 & 41.35 & 27.50 & 13.50 & 3.59 & 0.57 & 610.11 & 17.03 & 26.67 & 143.39 & 10.18 & 3.02 \\
\hline 16 & 1.52 & 0.06 & 13.98 & 6.90 & 6.57 & 1.32 & $<0.03$ & 115.99 & 3.52 & 6.95 & 39.63 & 0.77 & 2.62 \\
\hline TEL / $\left(\mu \mathrm{g} \mathrm{g}^{-1}\right)$ & $\mathrm{x}$ & 0.70 & 52.30 & 18.70 & $\mathrm{x}$ & $\mathrm{x}$ & 0.13 & $\mathrm{x}$ & 15.90 & 30.20 & 124.00 & $\mathrm{x}$ & $\mathrm{x}$ \\
\hline $\mathrm{PEL} /\left(\mu \mathrm{g} \mathrm{g}^{-1}\right)$ & $\mathrm{x}$ & 4.21 & 160.00 & 108.00 & $\mathrm{x}$ & $\mathrm{x}$ & 0.70 & $\mathrm{x}$ & 42.80 & 112.00 & 271.00 & $\mathrm{x}$ & $\mathrm{x}$ \\
\hline
\end{tabular}

$\mathrm{x}$ : TEL and PEL values were not presented in Canadian Sediment Quality Guidelines. 
close areas. Silva et al. ${ }^{6}$ recorded a considerable variation in granulometric data even in the same sampling station. In this study, mud content in site 14 was lower than those found in sites 13 and 15, which were not far from site 14 . Also, the grab sampler should have been released in areas where mud content was low.

TOC varied from 0.43 (site 10) to $7.79 \%$ (site 6). The metal availability to biota is also influenced by TOC percentage. According to USEPA, ${ }^{16}$ in many previous studies that evaluated this availability in sand and mud content, values of TOC above $0.5 \%$ were responsible for the most part of metal precipitation. Comparing TOC values with mud content, there is no apparent trend of distribution between both parameters. However, according to Yu et al. ${ }^{17}$ different chelating variables can compete dynamically to absorb metals becoming difficult the comprehension of absorption and release processes of metals.

\section{Pearson's correlation and principal component analysis (PCA)}

Pearson's correlation is summarized in Table 3. Mud content presented high significant correlation $(\mathrm{p}<0.01)$ for all metals except for $\mathrm{Mn}$ (with non significant correlation, $\mathrm{p}>0.05)$. Hg correlation with mud was the highest among metals confirming Hortellani et al. ${ }^{15}$. Al and Fe (commonly used for normalization) presented significant correlation with other metals. In general, except for $\mathrm{Hg}$ and $\mathrm{Mn}$ (with non significant correlation, $\mathrm{p}>0.05$ ), all metals showed to be strongly correlated, suggesting a generalized dissemination of these metals in the Santos Estuarine System. All metals and mud content showed no significant correlation with TOC $(\mathrm{p}>0.05)$. However, groups of metals with similar behavior were not detected by this analysis.

In order to identify probable groups correlated and to study the interrelationships among variables (metals and sites) and also the general behavior of data, the principal components analysis (PCA) was applied.

In this study, PCA indicated that 13 variables and 16 sediment samples can be represented by three significant PC (principal components) which presented variance above or close to $10 \%$ or eigenvalues above or close to 1 . These PC explained together $92.85 \%$ of the total variance in the original data set.

The PC1 summarized information about all metals and mud content. The following correlation of PC1 with each metal and mud content are presented: $\mathrm{Al}(0.968), \mathrm{Cd}$ (0.922), $\mathrm{Cr}$ (0.949), Cu (0.958), Co (0.874), Fe (0.978), Hg (0.760), Mn (0.691), Ni (0.9714), Pb (0.928), Zn (0.922) and Mud (0.825). These results supported the fact that PC1 was predominant and accounted for about $75 \%$ of total variance. The PC2 (which explained $11.03 \%$ of variance) only summarized information about TOC, Mn, $\mathrm{Hg}$ and mud content. These parameters presented the following correlation values with PC2: TOC $(0.756), \mathrm{Mn}(-0.598)$, $\mathrm{Hg}(0.447)$ and Mud (0.411). The PC3, the less significant component, only summarized information about TOC (0.551) and $\mathrm{Hg}(-0.408)$.

The plot of the scores of PC1 versus $\mathrm{PC} 2$ and $\mathrm{PC} 1$ versus $\mathrm{PC} 3$ were reported (Figures 1a and 1b). As it can be observed in Figures 1a and 1b, the contamination in the Santos Estuarine System increased also as the increase of the obtained values by PC. Sites 5, 11, 12 13, 15 (which are close to industrial area, oil company and steel industry)

Table 3. Pearson's correlation for metals and mud content measured in sediment samples of the Santos Estuarine System $(\mathrm{n}=16)$

\begin{tabular}{|c|c|c|c|c|c|c|c|c|c|c|c|c|c|}
\hline Elements & $\mathrm{Al}$ & $\mathrm{Cd}$ & $\mathrm{Cr}$ & $\mathrm{Cu}$ & $\mathrm{Co}$ & $\mathrm{Fe}$ & $\mathrm{Hg}$ & $\mathrm{Mn}$ & $\mathrm{Ni}$ & $\mathrm{Pb}$ & $\mathrm{Zn}$ & Mud & TOC \\
\hline $\mathrm{Al}$ & 1 & & & & & & & & & & & & \\
\hline $\mathrm{Cd}$ & $0.843^{\mathrm{a}}$ & 1 & & & & & & & & & & & \\
\hline $\mathrm{Cr}$ & $0.9483^{\mathrm{a}}$ & $0.8459^{\mathrm{a}}$ & 1 & & & & & & & & & & \\
\hline $\mathrm{Cu}$ & $0.8867^{\mathrm{a}}$ & $0.8955^{\mathrm{a}}$ & $0.896^{\mathrm{a}}$ & 1 & & & & & & & & & \\
\hline $\mathrm{Co}$ & $0.8658^{\mathrm{a}}$ & $0.6903^{\mathrm{a}}$ & $0.7696^{\mathrm{a}}$ & $0.8586^{\mathrm{a}}$ & 1 & & & & & & & & \\
\hline $\mathrm{Fe}$ & $0.9737^{\mathrm{a}}$ & $0.8612^{\mathrm{a}}$ & $0.9720^{\mathrm{a}}$ & $0.9111^{\mathrm{a}}$ & $0.8388^{\mathrm{a}}$ & 1 & & & & & & & \\
\hline $\mathrm{Hg}$ & $0.7464^{\mathrm{a}}$ & $0.7479^{\mathrm{a}}$ & $0.5852^{\mathrm{b}}$ & $0.6562^{\mathrm{a}}$ & $0.7500^{\mathrm{a}}$ & $0.6894^{\mathrm{a}}$ & 1 & & & & & & \\
\hline Mn & $0.7322^{\mathrm{a}}$ & $0.503^{\mathrm{b}}$ & $0.8544^{\mathrm{a}}$ & $0.6127^{b}$ & $0.5198^{b}$ & $0.7717^{\mathrm{a}}$ & $0.220^{c}$ & 1 & & & & & \\
\hline $\mathrm{Ni}$ & $0.9460^{\mathrm{a}}$ & $0.8489^{\mathrm{a}}$ & $0.9257^{\mathrm{a}}$ & $0.9517^{\mathrm{a}}$ & $0.8617^{\mathrm{a}}$ & $0.9700^{\mathrm{a}}$ & $0.6739^{\mathrm{a}}$ & $0.6967^{\mathrm{a}}$ & 1 & & & & \\
\hline $\mathrm{Pb}$ & $0.8529^{\mathrm{a}}$ & $0.939^{\mathrm{a}}$ & $0.8919^{\mathrm{a}}$ & $0.9235^{\mathrm{a}}$ & $0.7534^{\mathrm{a}}$ & $0.8638^{\mathrm{a}}$ & $0.6439^{\mathrm{a}}$ & $0.6377^{\mathrm{a}}$ & $0.8497^{a}$ & 1 & & & \\
\hline $\mathrm{Zn}$ & $0.8404^{\mathrm{a}}$ & $0.9133^{\mathrm{a}}$ & $0.8912^{\mathrm{a}}$ & $0.9572^{\mathrm{a}}$ & $0.7144^{\mathrm{a}}$ & $0.8916^{\mathrm{a}}$ & $0.5418^{b}$ & $0.6421^{\mathrm{a}}$ & $0.9212^{\mathrm{a}}$ & $0.9217^{\mathrm{a}}$ & 1 & & \\
\hline Mud & $0.8039^{\mathrm{a}}$ & $0.750^{\mathrm{a}}$ & $0.6557^{\mathrm{a}}$ & $0.7183^{\mathrm{a}}$ & $0.8152^{\mathrm{a}}$ & $0.7856^{\mathrm{a}}$ & $0.9339^{\mathrm{a}}$ & $0.332^{\mathrm{c}}$ & $0.7825^{\mathrm{a}}$ & $0.6706^{\mathrm{a}}$ & 0.6205 & 1 & \\
\hline TOC & $0.110^{\mathrm{c}}$ & $0.389^{\mathrm{c}}$ & $0.075^{\mathrm{c}}$ & $0.1817^{\mathrm{c}}$ & 0.0539 & $0.166^{\mathrm{c}}$ & $0.260^{c}$ & $-0.135^{\mathrm{c}}$ & $0.1734^{c}$ & $0.216^{\mathrm{c}}$ & $0.238^{\mathrm{c}}$ & $0.346^{\mathrm{c}}$ & 1 \\
\hline
\end{tabular}

a Correlation is significant at the 0.01 level (2-tailed); ${ }^{\mathrm{b}}$ correlation is significant at the 0.05 level (2-tailed); ${ }^{\mathrm{c} n o n}$ significant correlation $\mathrm{p}>0.05$. 

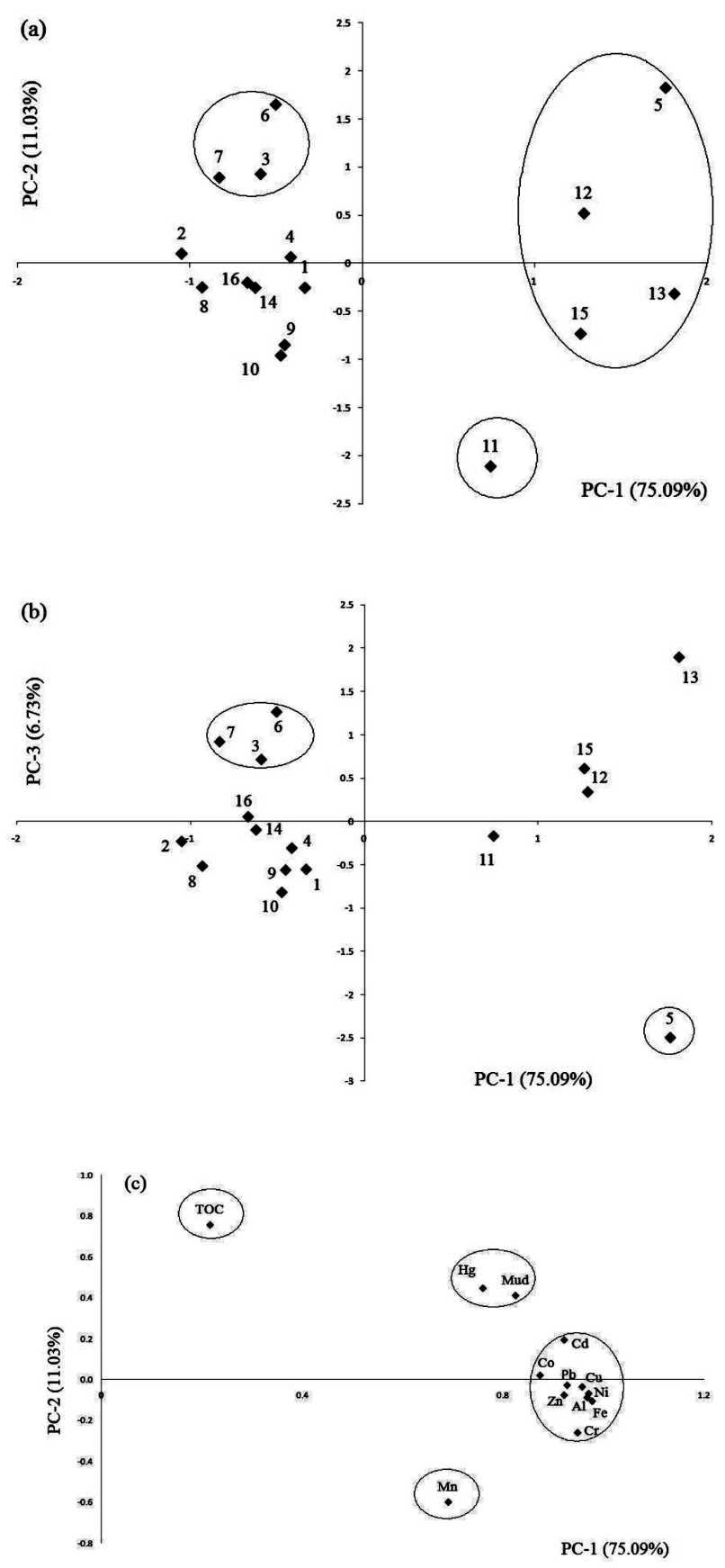

Figure 1. Scatter space plot of the principal components $(\mathrm{a}=\mathrm{PC} 1 \times \mathrm{PC} 2$; $\mathrm{b}=\mathrm{PC} 1 \times \mathrm{PC} 3$ of 16 sites and $\mathrm{c}=\mathrm{PC} 1 \times \mathrm{PC} 2$ of metals variables).

were distant from other sites. Site 5 presented higher $\mathrm{Hg}$ concentration than PEL and this site was separated from other sites in Figure $1 \mathrm{~b}$ because $\mathrm{Hg}$ was the only element that presented negative correlation with $\mathrm{PC} 3$. As previously reported on Table 2, concentrations of $\mathrm{Cu}, \mathrm{Hg}, \mathrm{Ni}$ and $\mathrm{Zn}$ were above TEL in sites 12,13 and 15 and $\mathrm{Pb}$ concentration was above TEL only in site 13 . Sites 5, 12, 13 and 15 were grouped, which suggests that they must be the most contaminated sites, justifying the PCA results. Site 11 also presented concentration of $\mathrm{Cu}, \mathrm{Hg}$ and $\mathrm{Ni}$ above TEL. However, the reason that separated this site from others in Figure 1a was the high concentration of $\mathrm{Mn}$ found in this site and the fact that Mn presented significant correlation with PC2 (-0.598).

It can also be observed that among sites with low contamination, a subgroup, including sites 3, 6 and 7, was separated from other sites due to being TOC percentage higher than $5.0 \%$, what may interfere in the metal availability to the biota. ${ }^{16,17}$

In the results presented in Figure 1c, a group formed by $\mathrm{Al}, \mathrm{Fe}, \mathrm{Cd}, \mathrm{Co}, \mathrm{Cr}, \mathrm{Cu}, \mathrm{Ni}, \mathrm{Pb}$ and $\mathrm{Zn}$, another group formed by $\mathrm{Hg}$ and mud content and one last group formed only by Mn were explained by PC1, confirming once more the influence of industrial activities. ${ }^{2}$ On the other hand, the group formed by mud content and $\mathrm{Hg}$ also showed to be explained by PC2 and Mn was significantly correlated with $\mathrm{PC} 2$. Once more, mud content and $\mathrm{Hg}$ showed to be related (Figure 1c), probably not only because of the contamination itself (since all values of $\mathrm{Hg}$ concentration were above Canadian limits) but also because of the high capacity of the grain to adsorb Hg. It confirms the dangerousness of $\mathrm{Hg}$ contamination, since this metal may be always available to biota.

Mn concentration was in agreement with values found in previous studies. ${ }^{2,6}$ The toxic effect of $\mathrm{Mn}$ in soil and aquatic environments depends on $\mathrm{Mn}$ concentration, $\mathrm{pH}$ value (Mn mobility increases as $\mathrm{pH}$ value decreases) and redox potential (Eh). Since $\mathrm{pH}$ and Eh conditions in estuarine systems favor the precipitation of $\mathrm{Mn}^{2}$ it is expected that this toxic effect might be reduced.

Since concentration values found for $\mathrm{Cd}$ were far below Canadian limits ${ }^{11}$ (Table 2), this element may also not be contaminant. Co concentration for some sites (5 and 12) was above those found in other studies. ${ }^{6,8}$ Since Co does not have TEL and PEL values for comparison to measured values, it seems that this element and $\mathrm{Cd}$ presented similar behavior and it may not be a contaminant.

\section{Cluster Analysis}

Cluster analysis is a useful tool for analyzing data sets for expected or unexpected clusters including the presence of outliers. The most similar points are grouped forming one cluster and the process is repeated until all points belong to one cluster. This analysis examines distances between samples and data sets. A dendrogram summarizing samples similarities is shown in Figure 2. The horizontal links correspond to sites and the numbers on the top of the dendrogram correspond to similarity level, in a scale from 0 (maximum identity) to 25 (maximum dissimilarity). 
Dendrogram using Ward method

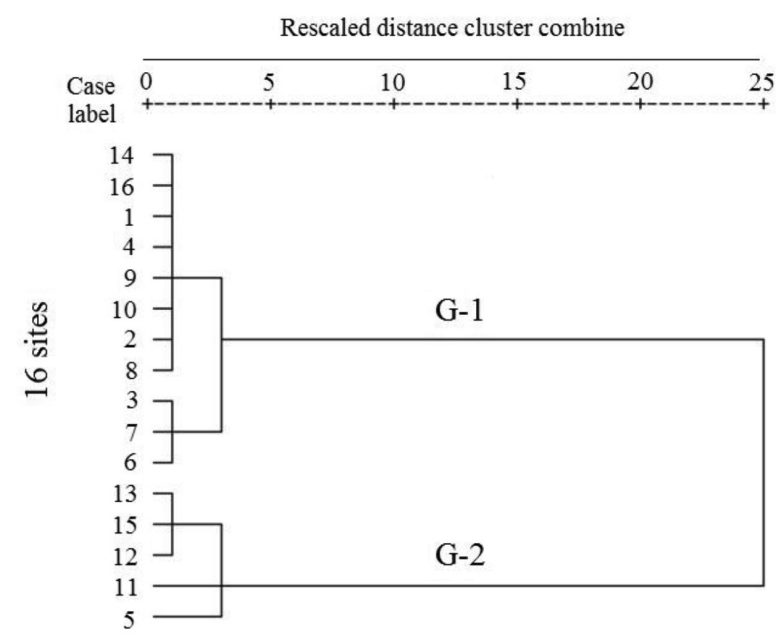

Figure 2. Dendrogram from the cluster analysis for metal concentrations in surface sediments collected from sites along the Santos Estuarine System.

Sites were clustered into two major groups (G1 and G2) separated by maximum dissimilarity among the metal content of the samples.

The characterizations of these groups were made by average value and standard deviation of each analyzed metal in these groups (Table 4). G2 (which contains 5 samples) presented metals with average concentration from 3.09 to 3.95 times above metal concentration of G1 (which contains 11 samples), suggesting that G2 corresponds to sites with critical contamination of sediment. Samples of G2 were collected in sites close to industrial area whereas $\mathrm{G} 1$ grouped sediment samples of non-contaminated sites.

Table 4. Characterization of groups by metal content

\begin{tabular}{lccc}
\hline Elements & $\mathrm{G} 1 * /\left(\mu \mathrm{g} \mathrm{g}^{-1}\right)$ & $\mathrm{G} 2 * /\left(\mu \mathrm{g} \mathrm{g}^{-1}\right)$ & $\mathrm{G} 2 / \mathrm{G} 1$ \\
\hline $\mathrm{Cu}$ & $8.12 \pm 4.27$ & $26.06 \pm 11.73$ & 3.21 \\
$\mathrm{Hg}$ & $0.163 \pm 0.089$ & $0.513 \pm 0.453$ & 3.15 \\
$\mathrm{Mn}$ & $152.92 \pm 85.91$ & $471.79 \pm 273.24$ & 3.09 \\
$\mathrm{Ni}$ & $4.98 \pm 2.66$ & $18.10 \pm 6.81$ & 3.63 \\
$\mathrm{~Pb}$ & $5.33 \pm 3.58$ & $21.05 \pm 11.57$ & 3.95 \\
$\mathrm{Zn}$ & $40.67 \pm 12.17$ & $135.20 \pm 65.23$ & 3.32 \\
\hline
\end{tabular}

*Mean \pm SD.

Figure 2 also shows that G2 (represented by samples of more contaminated sites) can be divided into 2 subgroups. The first group includes sites 12, 13 and 15, which presented sediment with the highest concentrations of $\mathrm{Cu}, \mathrm{Hg}, \mathrm{Mn}$, $\mathrm{Ni}, \mathrm{Zn}$ and $\mathrm{Pb}$ (most of them above TEL). The other subgroup includes site 5 (due to the $\mathrm{Hg}$ concentration that was obtained above PEL) and site 11 (due to the high $\mathrm{Mn}$ concentration).The results of cluster analysis confirmed those obtained by PCA.

\section{Conclusion}

From the results, it is concluded that metal contamination is still a problem for the bent ecosystem of the Santos Estuarine System. Metal concentrations above limit levels of Canadian Sediment Quality Guidelines were recorded. PCA grouped sites close to important industrial activities, where metals were found in high concentration. Cluster analysis confirmed PCA results. The serious damage caused by metals is sufficiently known to justify a strong environmental policy for the Baixada Santista (SantosSP, Brazil) to control effluent discharges in this estuarine system. Furthermore, strong efforts must be done to keep allowing recreation, fishing and other activities direct related to coastal areas and help protect the estuarine ecosystem.

\section{Supplementary Information}

Supplementary information (Figure S1, a map localizing the Santos Estuarine System and sites where sediments were sampled) is available free of charge at http://jbcs.org.br as a PDF file.

\section{Acknowledgements}

We would like to thank Fundação de Amparo à Pesquisa do Estado de São Paulo (FAPESP) for financial support.

\section{References}

1. Silva, W. L.; Machado, W.; Mattos, R H. R.; J. Braz. Chem. Soc. 2008, 19, 1490.

2. Lamparelli, M. L.; Costa, M. P.; Prósperi, V. A.; Bevilácqua, J. E.; Araújo, R. P. A.; Eysink, G. G. L.; Pompéia, S.; Sistema Estuarino de Santos e São Vicente. Arquivo Técnico, CETESB: São Paulo, Brasil, 2001.

3. Nizoli, E. C.; Silva, W. L.; Quim. Nova. 2009, 32, 365.

4. Cesar, A.; Choueri, R. B.; Riba, I.; Movales-Caselles, C.; Pereira, C. D. S.; Santos, A. R.; Abessa, D. M. S.; Del Valls, T. A.; Environ. Int. 2007, 33, 429.

5. Abessa, D. M. S.; Carr, R. S.; Rachid, B. R. F.; Sousa, E. C. P. M.; Hortellani, M. A.; Sarkis, J. E.; Mar. Pollut. Bull. 2005, 50, 875 .

6. Silva, W. L.; Matos, R. H. R.; Kristosch, G. C.; Machado, W.; Quim. Nova. 2006, 29, 256.

7. Cesar, A.; Abessa, D. M. S.; Pereira, C. D. S.; Santos, A. R.; Fernández, N.; Choueri, R. B.; DelValls, T. A.; Braz. Arch. Biol. Technol. 2009, 52, 233.

8. Hortellani, M. A.; Sarkis, J. E. S.; Abessa, D. M. S.; Sousa, E. C. P. M.; Quim. Nova. 2008, 31, 10. 
9. http://www.epa.gov/wastes/hazard/testmethods/sw846/ pdfs/3051a.pdf revised in February 2007, accessed in December 2010.

10. Abessa, D. M. S.; PhD Thesis, Instituto Oceanográfico, Universidade de São Paulo, São Paulo, SP, Brazil, 2002; available from the authors upon request.

11. http://www.ccme.ca/assets/pdf/sedqg_summary_table.pdf revised in 2001, acessed in December 2010.

12. Zar, J. H.; Biostatistical Analysis, $3^{\text {rd }}$ ed., Prentice-Hall: NJ, USA, 1996.

13. Cook, J. M.; Gardner, M. J.; Griffiths, A. H.; Jessep, M. A.; Ravenscroft, J. E.; Yates, R.; Mar. Pollut. Bull. 1997, 34, 637.
14. Cox, M. E.; Preda, M.; Mar. Pollut. Bull. 2003, 46, 1622.

15. Hortellani, M. A.; Sarkis, J. E. S.; Bonetti, J.; Bonetti, C.; J. Braz. Chem. Soc. 2005, 16, 1140.

16. http://www.epa.gov/nheerl/publications/files/ metalsESB_022405.pdf accessed in December, 2010.

17. Yu, K. C.; Tsai, L. J.; Chen, S. H. ; Ho, S. T.; Water Res. 2001, 35, 2417.

Submitted: January 19, 2011

Published online: July 14, 2011

FAPESP has sponsored the publication of this article. 


\title{
Metal Concentration in Sediments from the Santos Estuarine System: a Recent Assessment
}

\author{
Isabella C. A. C. Bordon, ${ }^{*, a}$ Jorge E. S. Sarkis, ${ }^{a}$ Gustavo M. Gobbato, ${ }^{a}$ \\ Marcos A. Hortellani ${ }^{a}$ and Claudia M. Peixoto ${ }^{b}$
}
${ }^{a}$ Centro de Química e Meio Ambiente, Instituto de Pesquisas Energéticas e Nucleares (IPEN), Av. Prof. Lineu Prestes no. 2242, Cidade Universitária, 05508-000 São Paulo-SP, Brazil
${ }^{b}$ Centro de Desenvolvimento da Tecnologia Nuclear (CDTN, campus da UFMG), Av. Pres. Antônio Carlos no. 6.627, 31270-901 Belo Horizonte-MG, Brazil

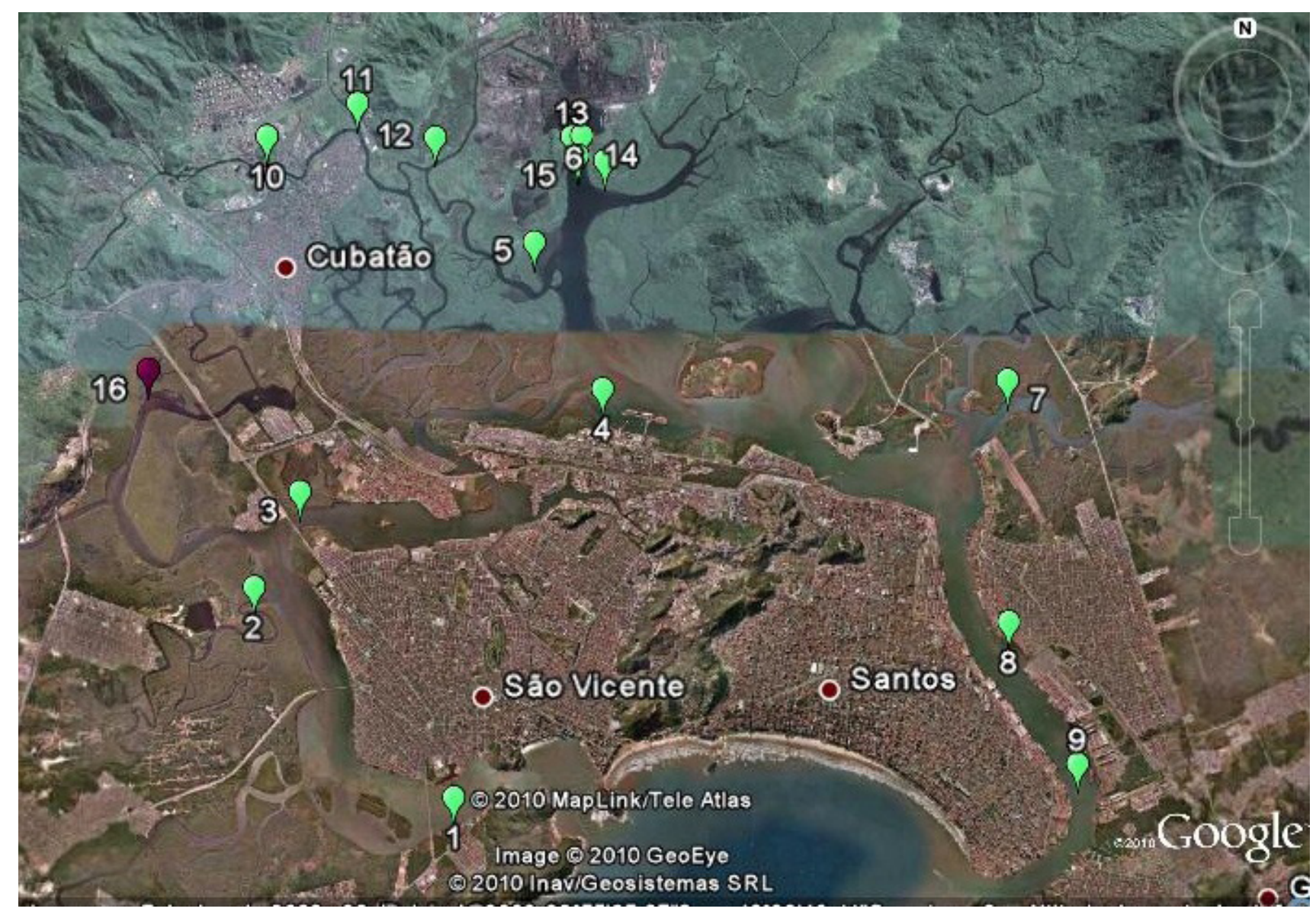

Figure S1. The Santos Estuarine System and sites where sediments were sampled. Important cities such as Santos, São Vicente and Cubatão are also indicated (source: Google Earth). 